\title{
1 Clinical genetics and its adjacent regimes
}

$2 \quad$ Lange $T .{ }^{l}$, Rigter $T .^{2}$, Vrijenhoek $T .^{l}$

$3{ }^{1}$ Department of Genetics, University Medical Centre Utrecht, Utrecht, The Netherlands

$4 \quad{ }^{2}$ Department of Clinical Genetics, Section Community Genetic \& Amsterdam Public Health

5 research institute, Amsterdam University Medical Center, Location VUmc, Amsterdam, The

6 Netherlands

\section{Abstract}

10 Clinical genetics is the prime application of genetics in healthcare, providing highly advanced

11 and reliable diagnostics for patients with (mostly rare) disease of genetic origin. Whereas

12 many novel technologies have expanded the genetic toolkit, integration or alignment with

13 other areas of healthcare is often challenging. We hypothesise that this is due to the

14 characteristics inherent to the regimes in which the genetic technologies were to be

15 implemented. In order to facilitate integration of genetic applications in a rebooting and

16 perhaps transforming healthcare system, we here provide insights in discrepancies between

17 clinical genetics and four of its adjacent regimes; public health, human genetic research, non-

18 genetic healthcare, and society. We conducted twelve semi-structured group interviews and a

19 focus group to collect information on overlapping and distinctive elements of each regime.

20 We identified three aspects in which the adjacent regimes differed considerably compared to

21 clinical genetics; perception of data, expectations from technologies, and

22 compartimentalisation units. Strikingly, divergence within each of these aspects was

23 determined by elements of culture, and not - as is often thought - by elements of structure,

24 e.g. regulation and policy. We conclude that implementation of genetics requires 
medRxiv preprint doi: https://doi.org/10.1101/2020.06.04.20102939; this version posted June 5, 2020. The copyright holder for this preprint (which was not certified by peer review) is the author/funder, who has granted medRxiv a license to display the preprint in perpetuity.

It is made available under a CC-BY 4.0 International license .

25 transdisciplinary empathy - understanding of the way of organizing, thinking and doing in

26 adjacent regimes.

27 
30 For two decades now, genetics has been destined to transform mainstream medicine ${ }^{1-6}$. To a

31 certain extend it has, considering the elaborate genetic toolkit with highly advanced

32 technologies and methodologies such as next-generation sequencing (NGS), genome-wide

33 association studies (GWAS) and Clustered Regularly Interspaced Short Palindromic Repeats-

34 associated nuclease 9 (CRIPR/Cas9). Still, the expected transformation of genetics into a

35 widely used solution to support prevention, treatment and cure of many diseases has not

36 occurred. Now - in a healthcare system that is gradually rebooting - there is an opportunity

37 to identify and shape the elements that have previously complicated optimal implementation

38 of genetics applications in healthcare.

40 A number of suggestions have been made to explain the relative low implementation rate of

41 genetics, e.g. technology outpacing capacity, lack of organizational structure, absence of a

42 collective sense of urgency, and disagreement on responsibilities ${ }^{7-9}$. In essence, healthcare is

43 notoriously resistant to change; initiating even the smallest changes necessitates attuning of

44 autonomous actors, consideration of effects beyond healthcare, and compelling evidence to

45 break with tradition ${ }^{10}$. On hindsight, envisioning a complete overhaul kickstarted by the mere

46 publication of the human reference genome - common sense in the early 2000 s - may have

47 been somewhat optimistic.

49 Still, various transitions in systems similar to healthcare have (recently) occurred, with the

50 energy transition as a prime example ${ }^{11-15}$. These transitions are characterized by two success

51 factors. First, the focus is on sustainability, not only thematically (e.g. environment, waste,

52 climate), but also in how technology was implemented (e.g. roof-top solar panels and direct- 
53 to-consumer (online) selling of electric cars). The transition drivers (unconsciously) adhere to

54 Amara's Law, which states that "we tend to overestimate the effect of a technology in the

55 short run and underestimate the effect in the long run"16. Second, there was a growing

56 understanding of the dynamics at the various system levels, e.g. on how sub-domains or

57 regimes can become interconnected because of shared niches ${ }^{17}$.

58

59 Here we put the developments in human genetics in a transition context. We consider the

60 most prominent sub-domain - clinical genetics - as the central regime, surrounded by

61 multiple adjacent regimes ${ }^{12}$. Preliminary explorations identified four genetics-affiliated

62 regimes, with varying degrees of overlap and distinction with respect to structure, culture and

63 practice $^{9}$.

64 


\section{Materials and methods}

66

67 We applied the "ambassador model of representation" for collecting input from various

68 stakeholders $^{18}$. Briefly, we interviewed representatives of each regime or subgroup thereof in

69 homogeneous duos or trios. From each interview group we invited one representative

70 ('ambassador') to participate in the multidisciplinary focus group (Figure 1).

Regime descriptions

73 Based on an initial literature scan, we identified four regimes that were closely connected -

74 partly entangled - with clinical genetics. We collected key characteristics of four adjacent

75 regimes - public health, human genetic research, primary and secondary healthcare, and

76 society - based on scientific literature and publicly available information.

Participants

79 Participants were recruited using purposeful sampling on the basis of the actor groups:

80 laboratory specialists (LS1-LS3), clinical genetics (CG1-CG2), researchers in human genetics

81 (HGR1-HGR3), non-genetic medical specialists (ngMS1-ngMS3), midwives (MW1-MW2),

82 care receivers (citizens and patients; CR1-CR11), and representatives from a public health

83 institute (PH1-PH3) and a funding agency (FA1). Participants of the focus group were

84 recruited during the group interviews. All participants consented for data collection and

85 publication.

\section{Group interviews}

88 To explore the perspectives of the different actor groups, we conducted twelve semi-

89 structured face-to-face homogeneous group interviews ( $\mathrm{n}=2-4$ per group, 26 in total: see 
medRxiv preprint doi: https://doi.org/10.1101/2020.06.04.20102939; this version posted June 5, 2020. The copyright holder for this preprint

(which was not certified by peer review) is the author/funder, who has granted medRxiv a license to display the preprint in perpetuity.

It is made available under a CC-BY 4.0 International license .

90 figure 1 for details). Homogenous participant groups of all relevant actors provided us with

91 profession-specific perceptions of the regime and also enabled elaboration on expectations of

92 other actor groups freely, without interference from other actors. All interviews were

93 conducted in the native language (Dutch). Most interviews lasted approximately 60 minutes.

Transcription and analysis

97 All interviews were transcribed verbatim and coded using a coding tree. To help closed

98 coding, the data analysis software ATLAS Ti was used. In addition to this closed coding, a

99 summary was made to ensure interesting quotes that did not belong in the coding tree were

100 captured (open coding). This was also used to assemble quotes for one aspect from various

101 actor groups in one document (axial coding). All coding was conducted by a single researcher

102 to ensure consistency.

103

104 Focus group

105 Most striking themes from the interviews gave guidance in the design of the focus group.

106 This entailed exercises to elaborate on: 1) what these actors exchanged; 2) the General Data

107 Protection Regulation; 3) technologies; and 4) which patients they helped. The focus group

108 lasted approximately three hours. The focus group was recorded and transcribed verbatim.

109 Selective coding was conducted based on preliminary results from the group interviews. An

110 observer took notes simultaneously to document non-verbal interaction such as nodding to

111 indicate approval or disagreement, facial expressions, and sphere. Two observers interpreted

112 discussions and summarized the most important conclusions.

113

114 
medRxiv preprint doi: https://doi.org/10.1101/2020.06.04.20102939; this version posted June 5, 2020. The copyright holder for this preprint (which was not certified by peer review) is the author/funder, who has granted medRxiv a license to display the preprint in perpetuity.

It is made available under a CC-BY 4.0 International license.

115

116 


\section{Results}

119 Starting from clinical genetics as a distinct regime, we explored four adjacent regimes -

120 public health, human genetics research, non-genetic healthcare, and society (Figure 2).

121 Literature and public information provided the key characteristics of each adjacent regime.

122 The group interviews and subsequent focus group provided deeper insight in the structure,

123 culture and practice of each regime, as well as determinants for adoption of genetics

124 applications in adjacent regimes.

\section{Public health}

128 Literature shows that public health emerged in the 1920s - simultaneous to modern medicine

129 - predominantly as a result of massive industralisation and urbanization ${ }^{12}$. It is generally

130 defined as "the science and the art of preventing disease, prolonging life and improving

131 quality of life" ${ }^{\prime 19}$. Vaccination, environmental safety, and lifestyle interventions are hallmark

132 public health services, which typically require national, coordinated action to ensure fully

133 distributed implementation. Or, as Participant PHI1 put it: "[public health institutes] are

134 amidst the triangle of practice, policy and science". Public health programs in the

135 Netherlands are usually upon directive from the Ministry of Public Health, Welfare and

136 Sports (VWS), and thus embedded in a structure of national regulation and financing, a

137 culture of prevention, and a practice at the local level (Table 1).

139 The most relevant public health service in the context of clinical genetics is (preventive)

140 population screening. This increasingly involves some form of genetic testing, either as part

141 of the first-tier test (e.g. neonatal screening) or as a follow-up (e.g. breast cancer screening) ${ }^{20}$. 
medRxiv preprint doi: https://doi.org/10.1101/2020.06.04.20102939; this version posted June 5, 2020. The copyright holder for this preprint

142 Whereas coordination of such programs is the responsibility of the national public health

143 institute, the actual testing is generally performed by 'field parties'. For instance, neonatal

144 screening is typically initiated by midwives and youth healthcare physicians, while

145 pediatricians and clinical geneticists take over if follow-up is required ${ }^{21}$. Similarly, the

146 national screening programs for breast, colorectal and cervical cancer occur under auspices of

147 the national public health institute, but the actual screening occurs at dedicated screening

148 centers. Other forms of genetic screening (e.g. preconception or pharmacogenetic), are not

149 (yet) fully established at the population level and offered on occasional basis ${ }^{22,23}$.

\section{Human genetics research}

152 Most innovations in clinical genetics have sprouted from human genetics research, a

153 scientific discipline with roots in the nineteenth century (Darwin, Mendel), which has vastly

154 matured since the publication of the human reference genome $\mathrm{e}^{3,4,24}$. Notwithstanding the

155 emerging wave of applications to edit particular genetic loci (i.e. through CRISPR/Cas), the

156 majority of human genetics research has been on the identification and understanding of

157 disease loci. Following the human reference genome publication, large efforts were

158 undertaken to map human genetic variation, and search for genetic variants underlying

159 disease. In particular the quest for disease loci divided the field; many research groups

160 performed large-scale genome-wide association study (GWAS) on common disease (e.g.

161 cancer or cardiovascular disease), while others performed smaller-scale mutation-detection

162 studies in patients with rare (syndromic) diseases (e.g. intellectual disability or congenital

163 disorders $)^{25,26}$. In total, more than $50.000+$ disease loci have been identified through GWASs,

164 but only few have resulted in a change in medical decision making ${ }^{25,27}$. Simultaneously,

165 many rare diseases have been 'solved', but due to their rarity they have only recently started

166 to get recognition as a significant public health issue ${ }^{28-30}$. Recently, the sub-communities 
medRxiv preprint doi: https://doi.org/10.1101/2020.06.04.20102939; this version posted June 5, 2020. The copyright holder for this preprint

(which was not certified by peer review) is the author/funder, who has granted medRxiv a license to display the preprint in perpetuity.

It is made available under a CC-BY 4.0 International license.

167 within human genetics have started to converge, providing first indications of a new

168 perspective on the 'evidence base' that is required for future genetic care ${ }^{31,32}$.

169

$170 \quad$ Non-genetic healthcare

171 Patients are generally referred to clinical genetics by other - non-genetic - medical

172 specialists, like pediatricians, oncologists, gynecologists, and - occasionally - general

173 practitioners. Secondary healthcare is structured according to specialty, either in a certain

174 organ system (urologist, cardiologist), patient type (pediatrician, gynecologist) type of care

175 (anesthesiologist, surgeon), or disease (oncologist). Historically, medical specialists have

176 evolved out of the physician constellation, and have rivaled with the remaining general

177 doctors (general practitioners) in terms of resources, status and recognition ${ }^{12}$. Since the

178 1930s, general practitioners have been considered the 'gateway' to healthcare, deciding on

179 referral of patients to further specialized care. Since the introduction of the registry of

180 medical specialists in 1973 (BIG), general practitioners have been recognized as a distinct

181 medical specialty, operating in relative autonomy. Growing individualization and a more

182 critical attitude in society at large has undermined the authority of medical specialists (e.g.

183 second opinion, media coverage $)^{12}$. Moreover, the recent trend towards constructing

184 multidisciplinary teams around particular patients has diminished the individual specialist's

185 autonomy ${ }^{33}$.

187 Society

188 Obviously, society as whole is broader than an individual regime, the actors interacting

189 directly with healthcare could collectively be considered the regime of 'care receivers'.

190 Traditionally, this would comprise patients, but especially in the case of clinical genetics this

191 may also comprise family members, and healthy individuals at-risk (e.g. in the case of breast 
192 cancer). In relation to healthcare, there is a great need for responsible use of personal data. In

193 Europe, this has culminated in the European General Data Protection Regulation (GDPR).

194 Meanwhile, the idea of what privacy entails is changing under the influence of internet and

195 communication technologies, which poses an additional layer of complexity to e.g. the

196 implementation of Electronic Health Records (EHR). Long-existing medical regulations (e.g.

197 in the Netherlands Article 2 of the Law on Special Medical Operations - Wbmv - and the

198 Population Screening Act - Wbo) have come under pressure as a result of developments in

199 medical technology and the perception of 'good care'. Finally, there is a society-wide

200 tendency for back-to-nature and healthy lifestyle products and a decreasing support for

201 (public) funding for (genetic) research, thus requiring novel business models to finance

202 healthcare innovation. 
medRxiv preprint doi: https://doi.org/10.1101/2020.06.04.20102939; this version posted June 5, 2020. The copyright holder for this preprint (which was not certified by peer review) is the author/funder, who has granted medRxiv a license to display the preprint in perpetuity.

It is made available under a CC-BY 4.0 International license .

Cross-over of genetics in adjacent regimes

205

206 The insights in the structure, culture and practice of the four regimes adjacent to clinical

207 genetics logically led to reflections on the impact of genetic applications on each regime, and

208 on the determinants for application of emerging genetic technologies. Three aspects were

209 frequently addressed as determinants for application: the use of data, the expectations from

210 technology and the level of transdisciplinary empathy.

211

212 "Our data generation levels are unsustainable; we simply will not be able to store all data."

213 (Participant LS1)

215 The actors within clinical genetics (clinical geneticists, laboratory specialists) were mostly

216 concerned with the mere volume of genetic data. Genetic laboratories follow self-imposed

217 national guidelines to mitigate capacity issues (e.g. delete raw data and intermediate analysis

218 files), but still have an annual spending of €50k-€100k on data storage. The a priori concern

219 is reproducibility; laboratories need to be capable of reproducing the original diagnosis.

220 Conversely, the actors in adjacent regimes put more emphasis on other dimensions of genetic

221 data. More specifically, each regime seemed to consider genetic data challenging, but for a

222 different reason. For instance, the researchers (human genetics research) experienced

223 challenges with respect to data access and use, particularly since the installment of the

224 Europe-wide General Data Protection Regulation (GDPR). Similarly, clinical geneticists

225 experience the practical implementation of the GDPR as burdensome. It especially causes

226 trouble concerning hereditary data sharing between family members as a consult should be

227 planned for every specific data sharing case. Participants ngMS1 and PHI1 indicated to

228 switch between their roles as respectively healthcare provider and policy maker, and that of a 
medRxiv preprint doi: https://doi.org/10.1101/2020.06.04.20102939; this version posted June 5, 2020. The copyright holder for this preprint (which was not certified by peer review) is the author/funder, who has granted medRxiv a license to display the preprint in perpetuity.

It is made available under a CC-BY 4.0 International license .

229 researcher to handle data issue appropriately. Conversely, the care receivers (society)

230 embraced the new data regulations as welcome safeguard for their personal data - not a

231 burden. In this context, participant FA1 stressed the importance of standardization, and the

232 efforts required to make data findable, accessible, interoperable and re-usable (FAIR).

"In 5 years? You will be considered a fool if you do not have yourself genetically screened

prior to reproduction."

(Participant ngMS1)

238

239 Clinical genetics is largely technology-driven, fed by developments in human genetics

240 research. Whereas the majority of genetic technologies have been developed to detect genetic

241 variation, much of the recent attention has gone to CRISPR/Cas, a technology that provides a

242 way to alter genetic variants. This affects the perception of genetic applications in society,

243 but also in the other adjacent regimes. For instance, the gynecologists and midwives (primary

244 and secondary care) anticipate a demand for 'designer babies' in their practices, which - in

245 their view - is the logical next step after non-invasive prenatal testing (NIPT), pre-

246 implantation genetic diagnostics (PGD) and screening (PGS) and preconception carrier

247 screening. Similarly, the program coordinator (funding agency) indicated to have set up

248 programs and work groups to explore applications of somatic gene therapy.

249 Remarkably, the perception of what was considered 'technology' varied considerably

250 between clinical genetics and adjacent regimes. A novel technology in clinical genetics is

251 generally linked to laboratory instruments (e.g. whole-exome sequencing (WES), whole-

252 genome sequencing (WGS) or CRISPR/Cas) which can be used for various applications.

253 Conversely, actors in primary and secondary care, public health, and society referred to the 
254 applications as 'novel technologies'. For instance, non-invasive prenatal testing (NIPT) is

255 considered a technology in gynaecology and obstrectics, while the actual testing comprises a

256 particular form of next-generation sequencing (NGS), which is considered the technology in

257 clinical genetics and human genetics research. Similarly, NGS is the laboratory technology

258 underlying 'gene panels' and 'screening'; the emerging technologies in the eyes of the

259 medical specialists in training (Figure 2).

260

261 Simultaneously, technology may be a determinant for the level of control and autonomy.

262 Participant PHI1 indicated that the decision to invest in building in-house technological

263 infrastructure strongly depends on the need to build independent expertise. Similarly clinical

264 geneticists and laboratory specialists are strict on quality, reliability and reproducibility, and

265 having in-house technology increases control over these aspects. Conversely, the focal point

266 of other medical specialists is on control over treatment decisions, and thus on being the

267 treating physician. This illustrates mixing genetic implications is perceived tricky, especially

268 when another specialized doctor is the treating physician of a patient with clinically relevant

269 genetic aspect.

270

"Every field has its own methods."

272 (Participant HGR1)

273

274 Medical specialists call it 'specialties', researchers talk about 'fields', and policy makers refer

275 to 'domains'. They all refer to the same phenomenon; their regime is structured into

276 compartments that operate in relative independence and isolation. The compartments in

277 clinical genetics are subspecialisations, e.g. oncogenetics, cardiogenetics, or neurogenetics.

278 Adjacent regimes are also highly siloed, but the determinants of separation vary considerably 
medRxiv preprint doi: https://doi.org/10.1101/2020.06.04.20102939; this version posted June 5, 2020. The copyright holder for this preprint

(which was not certified by peer review) is the author/funder, who has granted medRxiv a license to display the preprint in perpetuity.

It is made available under a CC-BY 4.0 International license .

279 between regimes. The subspecialisation in clinical genetics originates from the silos in

280 general healthcare, where doctors specialize in particular organ systems (e.g. urologist,

281 cardiologist), patient types (e.g. pediatrician, geriatrician), type of care (e.g. gynaecologists,

282 anesthesiologists), or disease (e.g. oncologist, syndromologist). The emergence of multi-

283 disciplinary teams increase permeability of silo walls, but it forces the specialists to gather at

284 the same (virtual) location at the same time, which can be challenging. Still, the clinical

285 geneticists consider the multidisciplinary teams as a sustainable future to withhold patients

286 from 'shopping around' with their own stories.

288 Human genetics research knows numerous fields, often linked to distinct disease categories

289 or biological concepts. The scientists considered commitment to a particular field as an

290 important factor in their career development; it provides visibility and a clear profile, which

291 is beneficial in the grant review process, where reviewers may think: 'Yeah, that and that

292 researcher, working on that and that'. On the other hand, if researchers' focus is too narrow,

293 it would slow down their research. Yet the main discriminator of silos is inherent to the

294 culture of science, and concerns the objective and corresponding research approach and

295 methodologies, with two major silos as a result; fundamental research and translational

296 research. The scientists referred to the aim as being the essence of the distinction between

297 fundamental and translational research, and its importance in finding sustainable healthcare

298 solutions. Fundamental research - as they see it - is meant to understand diseases, symptoms

299 and biological processes. The next step would be to translate, e.g. by predicting response of

300 an individual patient to a particular treatment. While hard criteria for what makes a researcher

301 fundamental or translational do not exist, the key seems to lay in the primary motivation. Of

302 the three scientists we interviewed, one indicated to be primarily curiosity-driven, one 
medRxiv preprint doi: https://doi.org/10.1101/2020.06.04.20102939; this version posted June 5, 2020. The copyright holder for this preprint

(which was not certified by peer review) is the author/funder, who has granted medRxiv a license to display the preprint in perpetuity.

It is made available under a CC-BY 4.0 International license .

303 preferred to do research with direct benefit for patients, and the third valued both motivations

304 equally.

305 Simultaneously, the increasing societal demand for instant revenues from public investments

306 in scientific research was recognized, especially among policy-oriented actors, i.e. from

307 funding agencies and public health institutes. The stakeholders generally navigate between

308 silos in policy, science and society, which can be challenging. For instance, participant PHI1

309 mentioned neonatal screening as an example where the policy area formally is prevention,

310 but relevant counseling occurs in a context of medical care. 


\section{Discussion}

313 Based on twelve group interviews and a focus group with genetics-affiliated professionals we

314 explored structure, culture and practice in four adjacent regimes of clinical genetics. Three

315 elements require specific attention when implementing genetic applications in adjacent

316 regimes - data, technology and silos.

318 Actors often point to structure - predominantly regulation - as major obstacle for

319 implementation of novel genetic application, while the underlying issue is often one of

320 culture. This is clearly illustrated - in this study and in literature - by the example of General

321 Data Protection Regulation (GDPR). Genetics professionals often perceive the GDPR as a

322 burden on their clinical or research practice, implying that the discrepancy between the

323 regime's structure and practice was caused by the regulatory newbie ${ }^{34}$. Yet the evolving

324 societal attitude towards data use - as expressed by the citizens in our study - indicates a

325 necessity to reconsider the existing culture (and resulting practice) towards use of genetic 326 data.

328 Similarly, the discriminators of silo-formation (structure) are largely defined by culture.

329 Clinical genetics is subspecialised according to the disease fields and organ systems that have 330 prevailed in modern medicine. The introduction of clinical genetics in the 1970s - when the

331 healthcare system had been largely institutionalized - forced the new medical specialty to fit

332 in the structure of the healthcare regime ${ }^{12}$. This has resulted in a culture of sub- or even

333 hyperspecialisation in clinical genetics. Conversely, the non-medical adjacent regimes are

334 also siloed, but in different directions. Public health is divided in curative and preventive 
medRxiv preprint doi: https://doi.org/10.1101/2020.06.04.20102939; this version posted June 5, 2020. The copyright holder for this preprint

(which was not certified by peer review) is the author/funder, who has granted medRxiv a license to display the preprint in perpetuity.

It is made available under a CC-BY 4.0 International license.

335 care, and human genetic research is predominantly divided into fundamental and translational

336 research.

337

338 Finally, the cultural discrepancies were even apparent from the perception of technologies.

339 Where researcher and lab analysists name underlying technologies of genome care, care

340 providers and -receivers address the care application.. Researchers were not aware of the

341 clinical implication of research; care providers were not aware of underlying technologies of

342 the clinical application nor of upcoming technologies.

343

344 Although generally not considered a regime in itself (landscape), the organisation of funding

345 and the role that funding agencies have in the distribution of resources strongly affects the

346 implementation of clinical genetics in adjacent regimes. For instance, research grants are

347 largely awarded based on publication records of individual researchers, which is difficult to

348 align with the activity-based reimbursement schemes in clinical genetics and other healthcare

349 regimes. Similarly, while alternative financing schemes are available for exceptional services

350 in healthcare (e.g. expensive medicine, in-vitro diagnostics), no such alternatives exist for

351 clinical genetics, hampering e.g. the application of whole-genome sequencing for multiple

352 diagnostics or prognostic purposes.

353

354 This study provides nuances to the observation that clinical genetics lacks organizational

355 structure, absence of agency, and attuning of stakeholders ${ }^{8,9}$. We acknowledge that an

356 overarching organizational structure and alignment is lacking, but this is rather due to the

357 lack of alignment between clinical genetics and its adjacent regimes, than to an absence of

358 structure. Therefore, attuning of stakeholders and creating a shared vision is important ${ }^{9}$. To

359 reach this shared vision, it is essential to first acknowledge that each investigated regime not 
medRxiv preprint doi: https://doi.org/10.1101/2020.06.04.20102939; this version posted June 5, 2020. The copyright holder for this preprint (which was not certified by peer review) is the author/funder, who has granted medRxiv a license to display the preprint in perpetuity.

It is made available under a CC-BY 4.0 International license .

360 only comprises genetic applications, but entails their own, non-genomic focused,

361 characteristic regime in abundance. We therefore recommend to be sensitive for the

362 differences with adjacent regimes, instead of trying to reshape these regimes, e.g. through

363 change agents ${ }^{9}$.

364

365 To conclude, the genome care regime cuts through the adjacent regimes of care, research,

366 institutions and care receivers. Each regime comprises signature cultural, technological,

367 industrial aspects. Transdisciplinary empathy towards adjacent regimes on those aspects

368 could lead to a more comprehensive regime of genome care.

369 
medRxiv preprint doi: https://doi.org/10.1101/2020.06.04.20102939; this version posted June 5, 2020. The copyright holder for this preprint (which was not certified by peer review) is the author/funder, who has granted medRxiv a license to display the preprint in perpetuity.

It is made available under a CC-BY 4.0 International license.

$3701 \quad$ Burton H. Genetics and mainstream medicine. 2011.

3712 Burton H, Hall A, Kroese M RS. Genomics in mainstream clinical pathways. PHG

$372 \quad$ Foundation, 2017.

3733 Lander ES, Linton LM, Birren B et al. Initial sequencing and analysis of the human

374 genome. Nature 2001. doi:10.1038/35057062.

3754 Craig Venter J, Adams MD, Myers EW et al. The sequence of the human genome.

$376 \quad$ Science (80- ) 2001. doi:10.1126/science.1058040.

3775 Reis-Filho JS. Next-generation sequencing. Breast Cancer Res 2009; 11: S12.

3786 Phimister EG, Feero WG, Guttmacher AE. Realizing genomic medicine. N. Engl. J.

379 Med. 2012. doi:10.1056/NEJMe1200749.

3807 Berg JS, Khoury MJ, Evans JP. Deploying whole genome sequencing in clinical

$381 \quad$ practice and public health: Meeting the challenge one bin at a time. Genet. Med. 2011.

382 doi:10.1097/GIM.0b013e318220aaba.

3838 Holtkamp KCA, Vos EM, Rigter T, Lakeman P, Henneman L, Cornel MC.

384 Stakeholder perspectives on the implementation of genetic carrier screening in a

385 changing landscape. BMC Health Serv Res 2017; 17: 146.

3869 Rigter T, Henneman L, Broerse JEW et al. Developing a framework for

387 implementation of genetic services: learning from examples of testing for monogenic

388 forms of common diseases. J Community Genet 2014; 5: 337-347.

38910 Rotmans J. Societal Innovation: between dream and reality lies complexity.

390 2005https://econpapers.repec.org/RePEc:ems:euriar:7293.

39111 van Raak R, de Haan FJ. Key features of modern health systems. In: Toward

392 Sustainable Transitions in Healthcare Systems. 2018 doi:10.4324/9781315232133-3.

39312 van Raak R. Transition Policies; connecting system dynamics, governance and

394 instruments in an application to Dutch Healthcare. 
medRxiv preprint doi: https://doi.org/10.1101/2020.06.04.20102939; this version posted June 5, 2020. The copyright holder for this preprint (which was not certified by peer review) is the author/funder, who has granted medRxiv a license to display the preprint in perpetuity.

It is made available under a CC-BY 4.0 International license .

395 2016.http://hdl.handle.net/1765/80061.

39613 Loorbach D, Frantzeskaki N, Avelino F. Sustainability Transitions Research:

397 Transforming Science and Practice for Societal Change. In: Gadgil, A and Tomich, TP

398 (ed). ANNUAL REVIEW OF ENVIRONMENT AND RESOURCES, VOL 42.

ANNUAL REVIEWS: 4139 EL CAMINO WAY, PO BOX 10139, PALO ALTO, CA

400 94303-0897 USA, 2017, pp 599-626.

40114 Françoise J, Jan R. More evolution than revolution: transition management in public

$402 \quad$ policy. Foresight 2001; 3: 875-890.

40315 Raven R, Verbong G. Multi-regime interactions in the dutch energy sector: The case of

404 combined heat and power technologies in the Netherlands 1970-2000. Technol Anal

$405 \quad$ Strateg Manag 2007. doi:10.1080/09537320701403441.

40616 Ratcliffe S (ed.). 'Roy Amara 1925-2007, American futurologist'. In: Oxford

407 Essential Quotations. Oxford University Press: Oxford, 2016

408

doi:10.1093/acref/9780191826719.001.0001.

40917 Grin J, Rotmans J, Schot J. Transitions to sustainable development: New directions in

$410 \quad$ the study of long term transformative change. 2010 doi:10.4324/9780203856598.

41118 Schumann S, Gschmeidler B. Knowing, Relations and Trust - Citizens' Perceptions of

412 Whole Genome Sequencing for the Genetics Clinic of the Future. 2020.

41319 Winslow C-EEA. The untilled fields of public health. Science (80-. ). 1920; 51: 23-33.

41420 van der Meij KRM, Sistermans EA, Macville MVE et al. TRIDENT-2: National

415 Implementation of Genome-Wide Non-Invasive Prenatal Testing as a First-Tier

$416 \quad$ Screening Test in the Netherlands. Am J Hum Genet 2019.

417 doi:https://doi.org/10.1016/j.ajhg.2019.10.005.

41821 Blom M, Bredius RGM, Weijman G et al. Introducing Newborn Screening for Severe

419 Combined Immunodeficiency (SCID) in the Dutch Neonatal Screening Program. Int J 
medRxiv preprint doi: https://doi.org/10.1101/2020.06.04.20102939; this version posted June 5, 2020. The copyright holder for this preprint (which was not certified by peer review) is the author/funder, who has granted medRxiv a license to display the preprint in perpetuity.

It is made available under a CC-BY 4.0 International license .

NEONATAL Screen 2018; 4. doi:10.3390/ijns4040040.

42122 Henneman L, Borry P, Chokoshvili D et al. Responsible implementation of expanded

$422 \quad$ carrier screening. Eur J Hum Genet 2016; 24: e1-e12.

42323 Bank PCD, Swen JJ, Guchelaar HJ. Estimated nationwide impact of implementing a

424 preemptive pharmacogenetic panel approach to guide drug prescribing in primary care

425 in The Netherlands. BMC Med 2019; 17: 110.

42624 Collins FS, Lander ES, Rogers J, Waterson RH. Finishing the euchromatic sequence of 427 the human genome. Nature 2004. doi:10.1038/nature03001.

42825 MacArthur J, Bowler E, Cerezo M et al. The new NHGRI-EBI Catalog of published 429 genome-wide association studies (GWAS Catalog). Nucleic Acids Res 2016; 45:

$430 \quad$ D896-D901.

43126 Gilissen C, Hoischen A, Brunner HG, Veltman JA. Disease gene identification

$432 \quad$ strategies for exome sequencing. Eur J Hum Genet 2012; 20: 490-497.

43327 Tam V, Patel N, Turcotte M, Bossé Y, Paré G, Meyre D. Benefits and limitations of 434 genome-wide association studies. Nat Rev Genet 2019; 20: 467-484.

43528 Angelis A, Tordrup D, Kanavos P. Socio-economic burden of rare diseases: A

436 systematic review of cost of illness evidence. Health Policy (New. York). 2015.

437 doi:10.1016/j.healthpol.2014.12.016.

43829 Forman J, Taruscio D, Llera VA et al. The need for worldwide policy and action plans

439 for rare diseases. Acta Paediatr 2012; 101: 805-807.

$44030 \quad$ Perkins BA, Caskey CT, Brar P et al. Precision medicine screening using whole-

441 genome sequencing and advanced imaging to identify disease risk in adults. Proc Natl

$442 \quad$ Acad Sci 2018; 115: 3686 LP - 3691.

$443 \quad 31 \quad$ Ashley EA. Towards precision medicine. Nat Rev Genet 2016; 17: 507-522.

44432 Green RC, Goddard KAB, Jarvik GP et al. Clinical Sequencing Exploratory Research 
medRxiv preprint doi: https://doi.org/10.1101/2020.06.04.20102939; this version posted June 5, 2020. The copyright holder for this preprint (which was not certified by peer review) is the author/funder, who has granted medRxiv a license to display the preprint in perpetuity.

It is made available under a CC-BY 4.0 International license.

445 Consortium: Accelerating Evidence-Based Practice of Genomic Medicine. Am J Hum

$446 \quad$ Genet 2016; 99: 246.

44733 NICE. Multidisciplinary team meetings. In: Emergency and acute medical care in over 448 16s: service delivery and organisation. 2018.

44934 Shabani M, Borry P. Rules for processing genetic data for research purposes in view of 450 the new EU General Data Protection Regulation. Eur J Hum Genet 2018; 26: 149-156.

451

452 


\section{Figure legends}

455 Figure 1. Participants and study design. Nine actor groups were included, and initially

456 interviewed in homogeneous group interviews. From each of the 9 actor groups, one

457 representative ('ambassador') was invited to participate in the subsequent focus group.

459 Figure 2. Clinical genetics and adjacent regimes. Starting from clinical genetics as the

460 regime under study (central circle), the adjacent regimes (dark grey) are public health, human

461 genetic research, non-genetic care and society. Other regimes (light grey) affect clinical

462 genetics mildly or indirectly, and are therefore not part of this study. The interaction between

463 clinical genetics and adjacent regimes is determined by the perception on data use (blue),

464 expectations from shared technologies (green) and the discriminator for

465 compartimentalisation (red). NGS = next-generation sequencing; GWAS = genome-wide

466 association studies; NIPT = non-invasive prenatal testing; PGD = pre-implantation genetic

467 diagnostics. Adapted from Van Raak et al. ${ }^{12}$ 
1 Table 1. Regime characteristics of clinical genetics and its adjacent regimes.

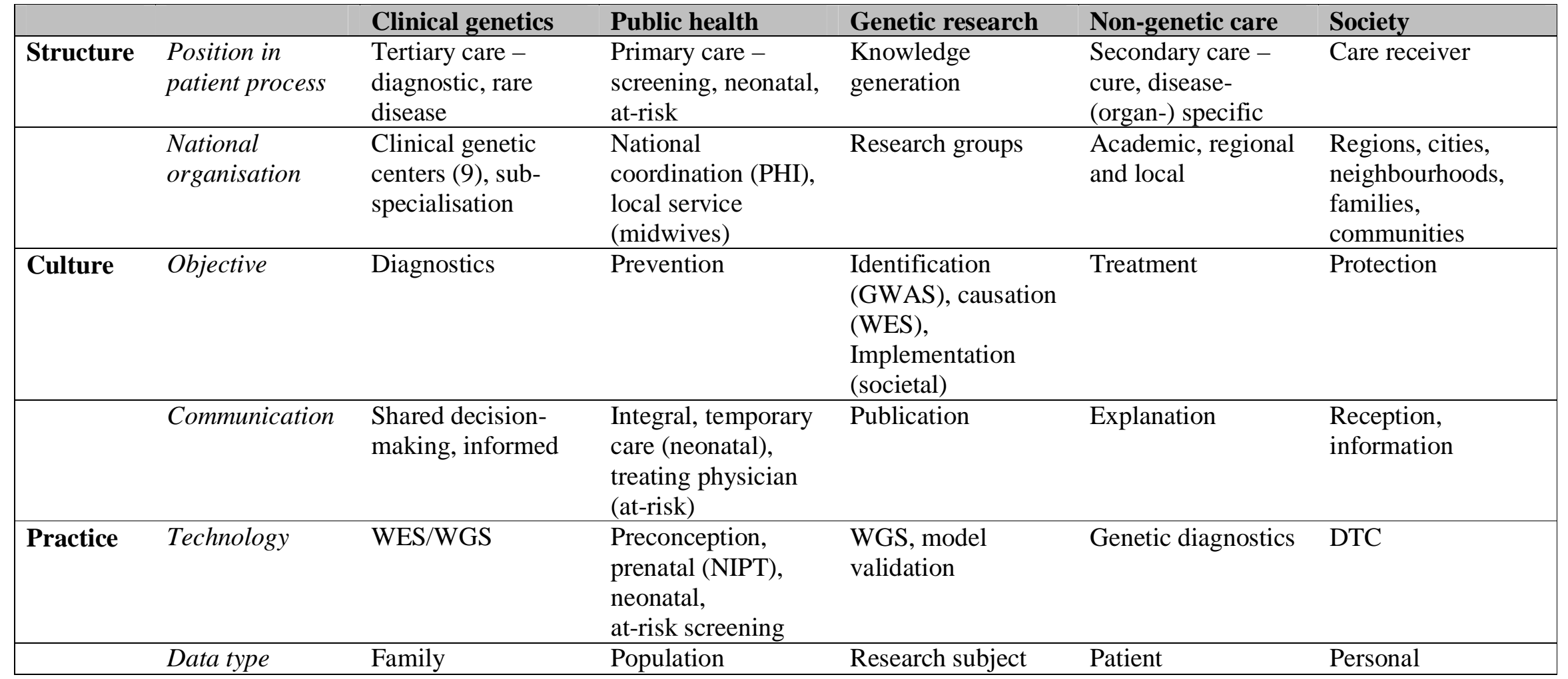

2 
